\title{
Influence of dietary components on development of the microbiota in single-stomached species
}

\author{
Eva Bauer ${ }^{1,2}$, Barbara A. Williams ${ }^{2}$, Hauke Smidt ${ }^{3}$, Rainer Mosenthin ${ }^{1}$ and Martin W. A. Verstegen ${ }^{2}$ \\ ${ }^{1}$ Institute of Animal Nutrition, University of Hohenheim, Emil-Wolff-Strasse 10, D-70599 Stuttgart, Germany \\ ${ }^{2}$ Animal Nutrition Group, Wageningen Institute of Animal Sciences, Wageningen University, Marijkeweg 40, 6709 PG \\ Wageningen, The Netherlands \\ ${ }^{3}$ Laboratory of Microbiology, Wageningen University, Hesselink van Suchtelenweg 4, 6703 CT, Wageningen, The Netherlands
}

\begin{abstract}
After birth, development of a normal microbial community occurs gradually, and is affected by factors such as the composition of the maternal gut microbiota, the environment, and the host genome. Diet also has a direct influence, both on composition and activity of this community. This influence begins with the milk, when specific components exert their growth-promoting effect on a beneficial microbiota, thereby suppressing potential pathogens. For example, breastfed infants compared with formula-fed babies usually have a microbial community dominated by bifidobacteria. When solid food is introduced (weaning), dramatic changes in microbial composition occur, so pathogens can gain access to the disturbed gastrointestinal (GI) ecosystem. However, use of specific dietary components can alter the composition and activity of the microbiota positively. Of all dietary components, fermentable carbohydrates seem to be most promising in terms of promoting proliferation of beneficial bacterial species. Carbohydrate fermentation results in the production of SCFA which are known for their trophic and healthpromoting effects. Fermentation of proteins, on the other hand, is often associated with growth of potential pathogens, and results in production of detrimental substances including $\mathrm{NH}_{3}$ and amines. In terms of the GI microbiota, lipids are often associated with the antimicrobial activity of medium-chain fatty acids and their derivatives. The present review aims to provide deeper insights into the composition and development of the neonatal GI microbiota, how this microbiota can be influenced by certain dietary components, and how this might ultimately lead to improvements in host health.
\end{abstract}

Diet: Fermentation: Gastrointestinal tract: Microbial community: Single-stomached species

\section{Introduction}

There is considerable interest in probiotics, prebiotics and, ultimately, in the promotion of gastrointestinal (GI) health in human nutrition. Concomitantly, with the ban on dietary antibiotics as growth promoters within the European Union, animal nutritionists are urgently seeking alternatives, particularly for young animals. Consequently, both sciences are now looking to each other's results and methodologies to find solutions for these issues.

There has long been an interest in differences between breast and formula milk in nutrition of human babies, and much research has focused on their differences in terms of development of the GI microbial community. For example, significant differences were found in the bacterial composition along the GI tract (GIT) between formulaand breast-fed infants (Stark \& Lee, 1982). For piglets, interest has focused on the time of abrupt weaning, which has always been a source of losses for the farmer. For both issues, it is only recently that new techniques in molecular biology are allowing dramatic advances in understanding the changes that occur in the whole microbial community, rather than only of selected species within that community.

In adult single-stomached species, a 'beneficial' commensal microbiota colonises the GIT in relationship with the host. One important aspect is the ability of this community to resist invasion by exogenous micro-organisms, which is known as 'colonisation resistance' (Van der Waaij et al. 1971). There 
are several mechanisms by which such resistance is achieved. For example, the action of antimicrobial metabolites (Walker \& Owen, 1990), or the maintenance of a lower $\mathrm{pH}$, may lead to reduced counts of pathogenic bacteria such as Escherichia coli (Sutton \& Patterson, 1996). Competition for adhesion sites and nutrients (Van der Waaij et al. 1971) is another mechanism by which such resistance could work. Young animals, however, need time to develop a complex community as well as their immune system and, until such developments have taken place, are vulnerable to the presence of potential pathogens in their GIT.

Diet is recognised as an important factor controlling microbial composition and activity in the GIT of singlestomached animals (Macfarlane et al. 1992), as it largely determines substrate availability for microbial fermentation (Cummings \& Englyst, 1987). For human infants, it has been suggested that a supply of complex carbohydrates might alter the colonic microbiota, or induce appropriate microbial enzymes, leading to improved fermentability of those substrates (Parrett et al. 1997). Rats, aged 6 weeks old, fed a high-protein diet, showed increased populations of coliforms and clostridia, whereas rats fed a diet based on maize, wheat flakes, wheat middlings and soyabean meal, had increased lactobacilli (Chung et al. 1977). A supply of appropriate substrates for microbial fermentation might therefore encourage development and maintenance of a beneficial GI microbial community, thereby supporting any health-promoting effects of that community. These effects include 'colonisation resistance', stimulation of SCFA production, and reduced production of potentially harmful substances. Fermentable carbohydrates are considered to be most promising in terms of a positive influence on the composition and activity of the indigenous microbiota of the GIT (Gibson \& Roberfroid, 1995; Williams et al. 2001).

Dietary modulation of the GI microbiota is of special interest for the young animal or infant, at times of change or stress, such as the time of intestinal colonisation immediately after birth, or at the time of weaning. In the present review, aspects concerning the influence of maternal milk and/or colostrum are described, including the proteins, carbohydrates and fats which have been shown to have an effect on colonisation of the neonatal GIT. The effects of different nutrients on GI microbial composition are also described, especially that of fermentable carbohydrates. Reference is made to protein fermentation, and to the effects of some lipids on bacterial composition. The present review includes data mainly from pigs and human subjects, but also some from studies on rodents and dogs.

\section{The gastrointestinal microbiota: a brief overview}

The total number of microbial cells within the GIT of singlestomached animals, including man, exceeds that of the host cells by at least one order of magnitude (Savage, 1977). These bacteria are constantly interacting with each other, and with the host, comprising a highly complex ecosystem of which comparatively little is known. The colon contents support at least 400 different species, with numbers as high as $10^{10}$ and $10^{11}$ culturable bacteria/g digesta (Savage, 1977; Mackie \& White, 1997). In pigs, the majority of the largeintestinal microbiota are obligate anaerobes, though some aerobic and facultative micro-organisms also exist (Varel \& Yen, 1997). The emergence of new molecular techniques has shown that the culturable fraction of the GI microbiota is probably only 10 to $50 \%$ of the total (Amann et al. 1995; Vaughan et al. 2000). These new methods enable the detection of microbial species that are either difficult or impossible to cultivate (O'Sullivan, 1999; Vaughan et al. 2000; Tannock, 2001). Methods based on genes encoding $16 \mathrm{~S}$ rRNA have been used to examine differences in the GI bacteria in various host species, such as man (Tannock et al. 2000), pigs (Leser et al. 2002), chickens (Netherwood et al. 1999) and mice (Walter et al. 2000).

There is some interest in seeing the extent to which the lumen microbiota resembles that attached to the mucosa of the intestine, though there are often methodological difficulties in obtaining representative samples. Using $16 \mathrm{~S}$ rRNA, Zoetendal et al. (2002) compared faecal communities with biopsy samples from the different parts of the human colon, and found differences between them. Differences in the structure of communities in human faecal and colonic contents were also observed using dot blot hybridisation and cultivation (Marteau et al. 2001). Zoetendal et al. (2002) also reported that the predominant mucosa-associated bacterial communities in the human GIT were host specific. This was in agreement with Simpson et al. (2000), who found, by use of 16S rRNA gene-targeted PCR and denaturing gradient gel electrophoresis fingerprinting in pigs, that each individual maintained a unique faecal bacterial community which was stable over time, suggesting a strong host influence.

From a functional point of view, Macfarlane et al. (1992) investigated human colon contents (including the ascending, transverse, and descending areas) of sudden-death victims, and showed that lumen conditions such as $\mathrm{pH}$ and concentration of fermentation products in these parts differed both between individuals, and between different areas of the GIT. Differences in microbial activity between individuals were also shown by comparing the in vitro fermentation capacity of microbial inocula from the large intestine (caecum, colon and rectum) of different pigs (Bauer et al. 2004). Using specific substrates, it was shown that there were significant differences in microbial activity between individuals both in terms of the rate and endproducts of fermentation.

To allow for studies of structure, function and dynamics of complex microbial ecosystems at sufficient resolution, novel culture-independent high-throughput approaches, including microarray techniques, are being developed (Zhou, 2003; Zoetendal et al. 2004).

\section{Development of the intestinal microbiota from birth}

After birth, the intestinal microbiota takes some time before developing a stable community (Gaskins, 2001). Colonisation is a complex process of natural selection and ecological succession. It depends on various factors, some of which are of host origin, such as the genome and physiology of the animal, while others are of microbial origin, such as bacterial interactions.

During the first few weeks of life, microbial succession in the GIT of human infants, pigs (Moughan et al. 1992), 
chickens (Barrow, 1992) and calves (Smith, 1965) is remarkably similar, even though other species are exposed to greater numbers of bacteria from faecal and environmental sources, compared with man. After birth, the germfree GIT is rapidly colonised by anaerobic and facultative anaerobic bacteria. Culture studies have indicated that in general, human infants are initially colonised by species showing a high reductive potential (for example, Enterobacter), which metabolise $\mathrm{O}_{2}$, thus indirectly encouraging the growth of anaerobic bacteria including lactobacilli and bifidobacteria, Bacteroides and clostridia (Mackie et al. 1999; Teitelbaum \& Walker, 2002). However, in human infants, it has also been shown that the composition of the intestinal microbiota varies according to the infants' diet. Several studies have shown that the microbiota of breast-fed infants is often dominated by bifidobacteria and lactobacilli, while the microbiota of formula-fed infants contains more Bacteroides, Clostridium and Enterobacteriaceae (Balmer \& Wharton, 1989). According to a study of Stark \& Lee (1982), breast-fed and formula-fed infants in the first week of life were colonised by enterobacteria and enterococci, followed by bifidobacteria, Bacteroides spp., clostridia and anaerobic streptococci. Until solid food was introduced at weaning, breast-fed babies had a simple microbiota consisting of bifidobacteria and relatively few enterobacteria and enterococci. Formula-fed babies during the corresponding period were more often colonised by other anaerobes in addition to bifidobacteria, and had higher counts of facultatively anaerobic bacteria. It would seem that breastfeeding created an intestinal environment that favours a simple microbiota of bifidobacteria and few other microorganisms (Bullen et al. 1976; Kleessen et al. 1995), although not all studies could confirm this result (Lundequist et al. 1985). The intestinal microbiota of the breast-fed infant may be composed of a relatively narrow spectrum of Gram-positive bacterial species, due to the presence of only a few dominant species in breast milk (Martín et al. 2003). More recently, such differences in microbial colonisation have been confirmed by molecular techniques (Harmsen et al. 2000). Favier et al. (2002) investigated the succession of bacterial communities in human neonates, by monitoring $16 \mathrm{~S}$ rRNA gene diversity in faecal samples using PCR-denaturing gradient gel electrophoresis. The first colonisers belonged to E. coli or Clostridium, followed after a few days by Bifidobacterium, which then remained predominant throughout breastfeeding. After weaning, Clostridium, Ruminococcus, Enterococcus and Enterobacter spp. appeared, with microbial denaturing gradient gel electrophoresis profiles becoming more complex and also more stable with increasing age.

Differences between the microbiota of breast-fed and formula-fed infants have also been shown with regard to differences in fermentative activity. According to Edwards $\&$ Parrett (2002), the ability of faecal microbiota from breast-fed infants to ferment complex carbohydrates seems to develop more slowly than that of formula-fed infants. In vitro fermentation of soyabean polysaccharide and guar gum was shown to increase progressively, but not to be significantly developed until late weaning
(Parrett et al. 1997). Differences in fermentative activities of formula-fed infants at different stages of weaning were not significant, which might indicate a faster maturation of their colonic microbiota (Parrett \& Edwards, 1997). However, in another study of Parrett et al. (1997), no differences in fermentation of several carbohydrates (soyabean polysaccharide and a fructo-oligosaccharide (FOS)) were found between faecal cultures of breast-fed and formula-fed infants, as measured by SCFA production. They showed that soyabean polysaccharides were poorly fermentable compared with faecal cultures from adults. Parrett \& Edwards (1997) suggested that one reason for this might be that before weaning, the intestinal microbiota of infants is primarily adapted to fermentation of lactose, hexoses and oligosaccharides from milk, with the consequence that enzymes needed to ferment other carbohydrates may be absent or inactive. The authors further suggested that ingestion of carbohydrates in the diet could stimulate the microbiota, and thereby improve the fermentation of such substrates (Parrett et al. 1997). However, McVeagh \& Miller (1997) suggested that the oligosaccharides present in human breast milk may act as 'soluble fibre' in the large intestine of human babies, providing a substrate which could stimulate microbial fermentation. This might lead to an adaptation of the infant's microbiota to fermentation of more complex carbohydrates, without the need for addition of other carbohydrates before weaning.

Differences in microbial composition may also occur when different milk formulae are fed. Hoey et al. (2004) used fluorescent in situ hybridisation with rRNA-targeted oligonucleotide probes to investigate the influence of a soya-based infant formula on faecal microbial composition in infants compared with cows' milk-fed controls, between 4 and 12 months of age. It was found that faecal bacterial numbers for bifidobacteria, bacteroides and clostridia (and total bacteria counts) were significantly lower for the soya group compared with the cows' milk group.

In suckling piglets, on the other hand, the population of faecal bifidobacteria seems to be numerically low (Mikkelsen et al. 2003), or even absent (Konstantinov et al. 2004a). Lactobacilli, however, establish early in the piglet's intestine, and, although succession does occur throughout the pig's lifetime, they remain a predominant member of the intestinal microbiota (Tannock et al. 1990; Naito et al. 1995; Stewart, 1997). At weaning, which generally occurs early, the transition from milk to a solid diet leads to dramatic changes in the composition of the microbial population during the $7-14 \mathrm{~d}$ after weaning (Hillman, 2001). According to Ewing \& Cole (1994), numbers of lactobacilli and other beneficial bacteria decrease in times of stress, as do their beneficial effects, allowing potential pathogens such as coliforms to increase. Franklin et al. (2002) found that lactobacilli populations in different GIT sections (jejunum, ileum, caecum) declined to lower levels in early-weaned pigs (17d), compared with pigs weaned at $24 \mathrm{~d}$. Konstantinov et al. (2004b) have reviewed recent studies investigating the GIT microbial diversity during weaning in piglets.

Offering creep feed to suckling piglets might alter the GI microbiota, thereby preparing it for the dietary challenges 
occurring after weaning (King \& Pluske, 2003). However, pre-weaning feed consumption is highly variable both between and within litters (Bruininx et al. 2002), and the amounts of creep feed ingested are often very small. Thus, mere provision of creep feed may not necessarily lead to any statistically significant changes in the GI microbiota (Jonsson \& Hemmingsson, 1991).

\section{Influence of maternal milk components on neonatal gastrointestinal tract microbial composition}

As for human infants, porcine milk contains a large variety of anti-inflammatory, antimicrobial and immunomodulatory agents, which may help to compensate for delays in development of the neonatal immune system or to support the establishment of a beneficial commensal microbiota. This is of particular importance in the pig, as their multilayered placenta prevents the transfer of maternal antibodies to the fetus. This contrasts with man and rodents, which benefit from a trans-placental passage of maternal serum antibodies during embryonic development (Butler, 1998; Salmon, 1999). Therefore, maternal antibodies, bioactive peptides such as growth factors and cytokines, as well as maternal cells such as phagocytes, lymphocytes and epithelial cells in mammary secretions, are of substantial importance in the early postnatal period in piglets (Salmon, 1999; Wagstrom et al. 2000). Immuno-active components present in mammary secretions of pigs have been reviewed by Wagstrom et al. (2000), and for human subjects by Labbok et al. (2004).

\section{Carbohydrates}

Milk can also contain components such as glycoproteins, glycolipids, mucins and oligosaccharides (Newburg, 1999), some of which exhibit antimicrobial activity, but which may also act as growth promoters for bifidobacteria (Kunz \& Rudloff, 1993). Mostly, these substances have been found in human milk, though some are also found in porcine milk, for example, lactoferrin (Masson \& Heremans, 1971). Compared with other host species, human milk is considered to be unique in terms of its complex oligosaccharide content (Rudloff \& Kunz, 1997).

Some oligosaccharides are known to be potent inhibitors of bacterial adhesion to epithelial cells by acting as receptor analogues to mucosal adhesion molecules (Kunz \& Rudloff, 1993; Kunz, 1998; Peterson et al. 1998). Such oligosaccharides have been shown to protect infants from many infectious agents (Carlson, 1985). Colonisation of epithelial surfaces is often the first step in the process of infection by a pathogen. Host-pathogen interactions are often mediated by the attachment of proteins (lectins) present on the microbial surface to oligosaccharide chains of glycoproteins and glycolipids on the eukaryotic cell (Karlsson et al. 1992). The pathogen protein-receptor sites have strict requirements for their oligosaccharide ligands, usually consisting of three to five monomers. This specificity is probably one of the main factors determining host species and site of initial colonisation. For example, lacto- $N$-tetraose and lacto$N$-neotetraose act as cell surface receptors for Streptococcus pneumoniae, while fucosylated oligosaccharides are receptors for E. coli. Kunz et al. (2000) summarised some of the oligosaccharides found in human milk, which are known to act as receptor analogues for bacterial pathogens.

Human milk oligosaccharides may act also as specific bifidogenic factors, supporting the survival of these bacteria (Beerens et al. 1980). Such natural prebiotics (3-6g/l in milk; Kunz \& Rudloff, 1993) consist mainly of a lactose core substituted with $N$-acetyl glucosamine, galactose, fucose and sialic acid, resulting in over 100 different compounds (Kunz \& Rudloff, 1993). Oligosaccharides in human milk have been shown to be resistant to enzymic hydrolysis in the upper GIT (Engfer et al. 2000; Gnoth et al. 2000).

\section{Proteins}

It has been assumed that significant bifidogenic activity may also be associated with milk protein (Bezkorovainy \& Topouzian, 1981; Petschow \& Talbott, 1990), either by direct stimulation of growth, or by antimicrobial effects. Liepke et al. (2002) showed that proteolytic fragments of major human milk proteins are effective growth factors for bifidobacteria. Secretory Ig is a highly protective agent, which can prevent colonisation and invasion by pathogens (for a review, see Brandtzaeg, 2003). The results of Liepke et al. (2002) showed that a proportion of secretory Ig may actually support growth of bifidobacteria. Lactoferrin, a glycoprotein which has been reported to promote the growth of bifidobacteria (Petschow \& Talbott, 1991; Hentges et al. 1992), has already been extensively discussed in terms of its antimicrobial activity (Sanchez et al. 1992). Both proteins may therefore be important in influencing an infant's intestinal microbiota, by exerting both antimicrobial effects and selective growth stimulation of bifidobacteria.

\section{Other compounds}

Human milk also contains nucleotides (Gil et al. 1986; Balmer et al. 1994) and gangliosides (Rueda et al. 1998), which, when added to formula milk have been shown to increase colonisation by bifidobacteria, although Balmer et al. (1994) could not confirm this finding. Bifidobacterial growth was also stimulated by the glycomacropeptide of bovine $\kappa$-casein (Poch \& Bezkorovainy, 1991) due to its glycan side chain. However, bovine glycomacropeptides also inhibit bacterial and viral adhesion (for a review, see Brody, 2000). Furthermore, antimicrobial action has been shown for a fragment of bovine casein- $\alpha_{\mathrm{s} 2}$ which is not present in human milk, and which inhibits growth of $E$. coli and Staphylococcus strains (Zucht et al. 1995). Bovine milk proteins such as $\alpha$-lactalbumin (Pellegrini et al. 1999) and $\beta$-lactoglobulin (Ouwehand et al. 1997) may also exert antimicrobial activity. Table 1 summarises some examples of components of human milk which exert antimicrobial or microbial growth-promoting activity, while Table 2 gives an overview of components of porcine milk and their putative influence on intestinal microbiota. 
Table 1. Components of human milk with possible influence on intestinal microbiota

\begin{tabular}{|c|c|c|}
\hline & Mode of action & Reference \\
\hline \multicolumn{3}{|l|}{ Antimicrobial agents } \\
\hline Lysozyme & $\begin{array}{l}\text { Bacteriolytic enzyme, cleaves peptidoglycans } \\
\text { in cell walls of bacterial pathogens }\end{array}$ & Chipman \& Sharon (1969) \\
\hline \multirow[t]{4}{*}{ Lactoferrin } & Fe-binding glycoprotein, inhibits growth & Bullen (1975) \\
\hline & of certain pathogens by competing with & Brock (1980) \\
\hline & bacteria for the ferric ion & Sanchez et al. (1992) \\
\hline & & Lönnerdal \& lyer (1995) \\
\hline \multirow[t]{3}{*}{ Lactoferricin } & Aminoterminal peptide of lactoferrin, exerts antibacterial & Tomita et al. (1991) \\
\hline & activity against Streptococcus mutans and & Yamauchi et al. (1993) \\
\hline & $\begin{array}{l}\text { Vibrio cholerae and inhibits attachment of } \\
\text { enteropathogenic Escherichia coli to intestinal cells }\end{array}$ & Edde et al. (2001) \\
\hline Oligosaccharides & $\begin{array}{l}\text { May function as receptor analogues that inhibit the } \\
\text { binding of enteric or respiratory bacterial } \\
\text { pathogens, or their toxins, to epithelial cells }\end{array}$ & Kunz \& Rudloff (1993) \\
\hline Mucins & $\begin{array}{l}\text { Heavily glycosylated milk proteins, interfere with } \\
\text { bacterial or viral adherence }\end{array}$ & Schroten (2001) \\
\hline \multirow{2}{*}{ Milk lipids } & $\begin{array}{l}\text { of neutral fats in milk may exert antiviral, } \\
\text { antibacterial and antiprotozoal activity }\end{array}$ & Issacs (2001) \\
\hline & $\begin{array}{l}\text { Milk fatty acids can damage bacteria by disrupting } \\
\text { their cell membranes }\end{array}$ & Hamosh (1998) \\
\hline \multicolumn{3}{|c|}{ Growth promoters of protective enteric bacteria } \\
\hline \multirow{5}{*}{$\begin{array}{l}\text { Lactoferrin or its proteolytic } \\
\text { generated fragments }\end{array}$} & Growth-promoting effect on bifidobacteria? & Petschow \& Talbott (1991) \\
\hline & & Hentges et al. (1992) \\
\hline & & Nuijens et al. (1996) \\
\hline & & Liepke et al. (2002) \\
\hline & & Griffiths et al. (2003) \\
\hline \multirow[t]{3}{*}{ Oligosaccharides } & Growth-promoting effect on bifidobacteria & György et al. (1974) \\
\hline & ('natural prebiotics') & Kunz \& Rudloff (1993) \\
\hline & & Newburg (1999) \\
\hline \multirow[t]{2}{*}{ Casein } & Glycoprotein, enhances proliferation of & Bezkorovainy \& Topouzian \\
\hline & Bifidobacterium bifidum & (1981) \\
\hline
\end{tabular}

\section{Influence of milk-associated bacteria}

Human breast milk provides a continuous source of microorganisms to the infant gut. It has been estimated that an infant consuming $800 \mathrm{ml}$ milk per d will ingest about $1 \times 10^{5}-1 \times 10^{7}$ bacteria while suckling (Heikkilä \& Saris, 2003). Bacteria commonly isolated from breast milk of healthy women have included staphylococci, streptococci, lactobacilli and enterococci (Gavin \& Ostovar, 1977; West et al. 1979). These bacteria should be considered as components of the milk, rather than as contaminants (Martín et al. 2004). Heikkilä \& Saris (2003) investigated bacterial diversity in expressed breast milk from healthy women. In this study, the predominant species were commensal staphylococci (64\%) and oral streptococci (30\%), with Staphylococcus epidermis, Strep. salivarius and Strep. mitis as the most common isolates. This agreed with earlier work which indicated that commensal staphylococci and streptococci were the predominant bacterial species in breast milk (Carroll et al. 1979; Eidelman \& Szilagyi, 1979; West et al. 1979), although they may have originated from the maternal skin during breast-feeding (West et al. 1979). Staphylococci and streptococci, especially Staph. epidermis and Strep. salivarius have also been identified from stool samples of breast-fed infants (for example, Kirjavainen et al. 2001; Favier et al. 2002), suggesting that infant faecal microbiota might reflect the bacterial composition of breast milk. Such commensal bacteria originating from breast milk may exert inhibitory effects against pathogens such as Staph. aureus (Heikkilä \& Saris, 2003). In a more recent study of Beasley \& Saris (2004), molecular methods were used to screen human milk for bacteria to reveal antibacterial activity caused by production of nisin, a bacteriocin produced by Lactococcus lactis. It has been suggested that nisin-producing L. lactis may protect mothers and infants from pathogenic skin bacteria, such as Staph. aureus (Pittard et al. 1991).

\section{Influence of dietary components on the gastrointestinal microbiota}

\section{Fats}

While significant knowledge is available on the toxic effect of dietary fat on ruminal micro-organisms (Jouany, 1994), only little is known concerning the influence of dietary fat on the GI bacteria of single-stomached animals. It has been suggested that dietary fat, if it escapes pre-caecal digestion, might reduce the number of micro-organisms in rats. This was supported by data showing a reduced methane production in pigs receiving fat in their diets (Christensen $\&$ Thorbek, 1987). However, in a human study, Cummings et al. (1978) found no effect of diets with high or low animal fat $(62$ or $152 \mathrm{~g} / \mathrm{d})$ on the relative numbers of faecal bacterial groups, including Enterobacteriaceae, Enterococcus, 
Table 2. Components of porcine milk with possible influence on intestinal microbiota

\begin{tabular}{llc}
\hline Agent & \multicolumn{1}{c}{ Putative mode of action } & Occurrence and reference \\
\hline Lysozyme & Bactericidal activity & Hill \& Porter (1974) \\
& Nagy et al. (1976) & Schulze \& Muller (1980) \\
& & Thoren-Tolling \& Martinsson (1974) \\
Transferrin & Antimicrobial & Elliot et al. (1984) \\
Lactoferrin & Antimicrobial & Masson \& Heremans (1971) \\
& Growth-promoting effect on beneficial bacteria? & Decuypere \& Dierick (2003) \\
Milk lipids & Antimicrobial effect? & (Low quantity of medium-chain fatty acids) \\
Oligosaccharides & Receptor analogue? Growth-promoting & Staples et al. (2002) \\
(Low quantity) & György et al. (1954) \\
'Bifidus factor' & effect on beneficial bacteria? & Holt \& Jenness (1984) \\
Casein & Growth-promoting effect on beneficial bacteria? & Kauf \& Kensinger (2002) \\
$\begin{array}{l}\text { Peptide produced by } \\
\text { casein digestion, for } \\
\text { example, casomorphin }\end{array}$ & Growth-promoting effect on beneficial bacteria? & Meisel (1986) \\
& Biologically (immunomodulatory) active? & Meisel \& Frister (1989)
\end{tabular}

Bacteroides, lactobacilli and clostridia. Kuda et al. (2000), on the other hand, showed a decrease in faecal Bacteroidaceae after feeding mice with fish oil, compared with mice fed beef tallow. Interestingly, the number of faecal bifidobacteria was greater for the fish oil-fed animals.

According to Dänicke et al. (1997), significantly higher $\mathrm{pH}$ values were measured in most intestinal segments of broiler chickens, when beef tallow was used as a dietary fat instead of soyabean oil. Dänicke et al. (1999) then investigated the effect of the same dietary fat types on selected bacterial groups adhering to the intestinal epithelium in broiler chickens. The beef tallow-fed animals showed increased numbers of cocci in the jejunum and ileum, but decreased total anaerobic bacteria and enterobacteria. However, from the study of Dänicke et al. (1999), it was not clear whether the growth of cocci was actively stimulated by beef tallow, or whether it occurred as a result of an inhibition of other species. For example, the secretion of bile acids may have been stimulated by the presence of beef tallow.

As detergents, bile acids possess potent antimicrobial activity. However, some members of the intestinal microbiota have developed mechanisms to resist their action (Gunn, 2000). Some cocci are distinguishable by their growth in the presence of bile salts and, thus, these bacteria, such as enterococci (Gunn, 2000; Strompfová et al. 2004), may become dominant when bile acid concentrations are increased. However, some lactobacilli can deconjugate conjugated bile acids (Tannock et al. 1994) though it is unknown whether such activity is sufficient to affect bile salt metabolism. The type of dietary fat may also influence the intestinal microbiota indirectly, through its impact on digesta viscosity, intestinal transit time, and digestion in the small intestine (Dänicke et al. 1999).

The antimicrobial activity of SCFA and medium-chain fatty acids (MCFA; fatty acids consisting of 6 to $12 \mathrm{C}$ ), as well as their derivatives, was first demonstrated by Kabara et al. (1972). Since then, antimicrobial activity of MCFA has been shown for group B Streptococcus and Haemophilus influenzae (Isaacs et al. 1995) and for Listeria monocytogenes (Wang \& Johnson, 1992), amongst others. Using both in vitro and in vivo models in mice, Petschow et al. (1998) showed antimicrobial activities of medium-chain monoacylglycerols on bacterial enteropathogens (for example, Vibrio cholerae or enterotoxigenic E. coli). The bactericidal effect of digestion products of bovine milk triacylglycerols was examined in vitro by Sprong et al. (2001). For all pathogenic bacteria tested (E. coli, Salmonella enteridis, Campylobacter jejuni, L. monocytogenes and Clostridium perfringens), C10 : 0 and C12 : 0 fatty acids were found to be toxic. Sphingosin, which is formed in the intestine from dietary sphingolipids (Schmelz et al. 1994), had the greatest bactericidal effect. Tsuchido et al. (1985), investigating the effect of SCFA and MCFA on Bacillus subtilis, found that the antimicrobial effect of MCFA could be mediated by the induction of an autolytic enzyme causing cellular lysis. Another mechanism proposed for the antimicrobial action of fatty acids is the destabilisation or disintegration of the cell membrane (Thormar et al. 1987; Isaacs, 2001). This latter mechanism was investigated by Bergsson et al. (2001) using MCFA and their monoacylglycerols on Gram-positive cocci. Monocaprin was shown to be the most effective agent against Staph. aureus.

However, the repellent odour and taste of such fatty acids makes their use as feed additives for young animals problematic, as a decreased feed intake would strongly compromise their efficacy. A further reduction in efficacy may result from the direct absorption of these acids in the stomach or proximal small intestine (Clark et al. 1969; Dierick et al. 2002b; Decuypere \& Dierick, 2003). It has been suggested that the in situ generation of MCFA originating from triacylglycerols containing MCFA might overcome this problem. The MCFA could then be released by exogenously supplied lipases, as well as endogenous preduodenal lipases which are present in several host species. Using in vitro and in vivo methods, Dierick et al. $(2002 a, b)$ investigated the effect of such a combination of triacylglycerols containing MCFA and exogenous lipolytic enzymes as feed supplements in piglets. Microbial counts showed a strong suppressive effect of the MCFA released by the exogenous enzymes on the intestinal microbiota in piglets, suggesting their use as an alternative for antimicrobial growth promoters. The possibilities and limitations of combining triacylglycerols containing 
MCFA and exogenous lipolytic enzymes as an alternative to in-feed antibiotics have been reviewed by Decuypere \& Dierick (2003).

\section{Proteins}

Proteins are known to be important substrates for some intestinal bacteria (Macfarlane et al. 1986). However, it has also been shown that several potential pathogens are predominantly protein-fermenters, and would therefore grow more prolifically when proteins are freely available (Macfarlane \& Macfarlane, 1995). For example, excessive protein intake was shown to favour the growth of undesirable species such as $C$. perfringens, and to reduce faecal counts of bifidobacteria. Under such conditions, faecal consistency was softer, and excretion of C. perfringens enterotoxin and other metabolic endproducts related to microbial protein decomposition was increased (Zentek, 1995a,b; Van der Steen et al. 1997).

\section{Fermentable carbohydrates}

The carbohydrate fractions, which escape digestion by mammalian enzymes and are therefore potentially available as substrates for microbial fermentation, include NSP (plant cell wall polysaccharides, pectins, gums), resistant starch and non-digestible oligosaccharides (NDO). The effect of these fractions on the GI microbiota is related to the availability of that carbohydrate to the bacteria as a substrate, i.e. to their fermentability. For example, the microbial breakdown of specific NSP is influenced by the chemical structure of the carbohydrate polymers present (Botham et al. 1998), such as the degree of lignification. It is generally assumed that the more soluble carbohydrates are more readily available and therefore fermentable (Stephen \& Cummings, 1979), though it has been shown that this is not always necessarily the case (Bauer et al. 2001). This study, using faecal inocula of unweaned piglets and cumulative gas production as a measure of fermentation kinetics (Williams et al. 2005), showed that insoluble fibre (soya hulls) was better fermented in terms of production of gas and SCFA, compared with a soluble substrate (guar gum).

Non-starch polysaccharides. The NSP (together with lignin) are the principal components of plant cell walls, which differ in their chemical composition and physical properties, both within and between plant sources. The main NSP structures commonly found in feed ingredients of plant origin are all non- $\alpha$-glucan polymers such as cellulose, $\beta$-glucans, arabinoxylans, arabinogalactans, galactomannans, xyloglucans and rhamnogalactouronans (pectins) (Cummings \& Englyst, 1987; De Lange, 2000). Pectins, which are usually included in the NSP fraction, are structurally based on a polymer of galacturonic acid residues with rhamnose and arabinose substituents. A variable proportion of the uronic carboxyl groups in pectin are esterified with methanol (Adrian, 1976). Gums, such as gum arabic (a complex arabinogalactan polysaccharide associated with a glycoprotein) and guar gum (a galacto-mannan), have been shown to be well fermented (Bauer et al. 2001).

Using anaerobic culture techniques to investigate faecal samples from pigs, Varel et al. (1984) showed that diets high in dietary fibre $(35 \%$ lucerne meal, compared with a control diet, $0 \%$ lucerne meal) increased the number of cellulolytic bacteria without changing the total number of microorganisms. Gums, on the other hand, have been shown to exert bifidogenic effects. Gum arabic is completely fermented in the human colon (Ross et al. 1983). Guar gum is readily fermented by the human faecal microbiota (Salyers et al. 1977), and also showed bifidogenic effects, during enteral feeding (Okubo et al. 1994).

$\beta$-Glucans are structural components of cereals (wheat and barley), and of fungal cell walls, which cannot be digested by mammalian enzymes, and are therefore potentially useful substrates for GI fermentation (Englyst et al. 1989; Edney et al. 1991). In poultry, they may exert negative effects on animal performance due to their viscosity, which has been shown to impair digestive and absorptive processes (Choct \& Annison, 1992; Fuller et al. 1995). However, they may have beneficial effects on microbial composition in terms of increasing the number of lactobacilli; Jonsson \& Hemmingsson (1991) showed a correlation between the diet of piglets and the occurrence of cultivable faecal lactobacilli with an ability to degrade $\beta$-Dglucans. Dongowski et al. (2002) investigated the effect of barley-rich diets on the GIT in young rats, and found decreased counts of coliforms and Bacteroides for rats fed the barley-based diets, with concomitant increased Lactobacillus counts. Also, SCFA production was higher for the barley-fed animals compared with the control group.

Guo (2003) investigated the effects of different polysaccharide fractions from the mushrooms Tremella fuciformis and Lentinus edodes, and from a herb, Astragalus membranaceus, on the caecal bacterial community of chickens in vitro. Specific PCR amplification of 16 S rRNA gene fragments in combination with denaturing gradient gel electrophoresis was used to analyse the microbial community before and after in vitro fermentation, using chicken caecal contents as the original inoculum. The polysaccharide extracts led to significant shifts in the bacterial community when fermented in vitro.

Resistant starch. According to Englyst et al. (1992), resistant starch is classified into three groups: type I, representing physically inaccessible starch such as whole or partly milled grains; type II, representing starch in granules such as raw potato; type III, representing retrograded starch produced by heat treatment during feed processing. More generally, resistant starch refers to the fraction of starch that escapes enzymic digestion in the human small intestine (for example, McBurney et al. 1988). The presence of resistant starch in feeds is related to many factors including the amylose:amylopectin ratio, the granule structure of the starch, the physical form of the feed, the effects of processing, and the presence or absence of NSP, amylase inhibitors, lectins and phytate (Cummings \& Englyst, 1987). For a recent review describing the classification of resistant starch, see Champ et al. (2003). 
Resistant starch provides a carbohydrate source for bacterial growth which has been shown to yield high concentrations of butyric acid (Wang et al. 2004). In man, the predominantly amylolytic bacteria belong to the genera Bifidobacterium, Bacteroides, Fusobacterium and Butyrivibrio (Cummings \& Englyst, 1987). Wang et al. (2002) examined four diets containing $40 \%$ amylopectin maize starch, amylomaize starch, carboxymethylated amylomaize starch or acetylated amylomaize starch, for their effect on the composition of colonic bacteria in mice. They found significant increases in the faecal bifidobacteria for mice fed the amylopectin, amylomaize and acetylated amylomaize starch diets. A significant decrease in the faecal population of coliforms was observed for mice fed acetylated amylomaize starch. A promoting effect on indigenous bifidobacteria of diets containing resistant starch has also been demonstrated for rats and pigs (Brown et al. 1997; Kleessen et al. 1997; Silvi et al. 1999).

Non-digestible oligosaccharides. The NDO fraction comprises carbohydrates such as FOS or inulin, and is currently the most popular candidate as a so-called 'prebiotic'. Prebiotics have been defined as specific ingredients which are added to the human diet and which are believed to enhance the beneficial activity of specific members of the microbiota, such as lactobacilli or bifidobacteria in the large intestine (Gibson \& Roberfroid, 1995). Inulin is a plant fructan which shows a degree of polymerisation ranging from two to sixty fructose units. Inulin molecules having a degree of polymerisation of less than twenty fructose units are generally defined as FOS, and are a mixture of predominantly tri-, tetra- and pentasaccharides (Gibson \& Roberfroid, 1995; Van Loo et al. 1995). Other NDO currently used as prebiotics include transgalacto-oligosaccharides (TOS) which are a mixture of tri-, tetra-, penta- and hexasaccharides (Ekhart \& Timmermans, 1996), and raffinose, which is widely distributed in plants (Rathbone, 1980). Other oligomers that may have a possible prebiotic effect include lactulose, and oligosaccharides containing xylose, mannose and galactose (Gibson \& Roberfroid, 1995). For a detailed listing and description of NDO currently used as prebiotics, see Grizard \& Barthomeuf (1999).

In vitro fermentation using human faeces showed that inulin and FOS selectively stimulate the growth of bifidobacteria and may produce an environment (increased SCFA concentrations and/or decreased $\mathrm{pH}$ ) that is not favourable to the growth of certain pathogenic organisms such as E. coli and C. perfringens (Wang \& Gibson, 1993). Generally, these substrates can be utilised by lactobacilli, Bacteroides, streptococci and enterobacteria, but are not utilisable by E. coli (Hidaka et al. 1986). McDonald (2001), using weaned piglets naturally colonised with haemolytic $E$. coli, reported decreased proliferation of $E$. coli in response to inulin in the diet. Xu et al. (2002) showed increased viable counts of Bifidobacterium and Lactobacillus in the small-intestinal and proximal colonic contents of pigs fed a diet supplemented with FOS (4 and $6 \mathrm{~g} / \mathrm{kg}$ diet), as compared with the control diet. Concomitantly, they found reduced counts of Clostridium and E. coli.
Kleessen et al. (2003) investigated the effect of fructanrich Jerusalem artichoke (as $0.5 \%$ syrup in drinking water) on viable counts of selected caecal bacteria in broiler chickens up to $35 \mathrm{~d}$ of age. The authors found that Jerusalem artichoke resulted in significantly smaller numbers of total aerobes, Enterobacteriaceae and C. perfringens, suggesting that the Jerusalem artichoke may have suppressed potential pathogens in broilers' caeca.

Studies using combinations of FOS and other NDO have also been performed. For example, Moro et al. (2002) analysed faecal samples from newborn infants who had received a formula supplemented with either 4 or $8 \mathrm{~g}$ of a mixture of FOS and galacto-oligosaccharides (GOS)/1 for 1 month. Compared with the control group receiving a nonsupplemented formula, there was a dose-dependent increase in the number of bifidobacteria and lactobacilli in the faecal samples after $28 \mathrm{~d}$. No significant change was observed in other components of the faecal microbiota, particularly Bacteroides, Clostridium, E. coli, Proteus and Klebsiella. Similarly, Boehm et al. (2004) found, by use of culture and fluorescent in situ hybridisation, that the addition of an oligosaccharide mixture (FOS and GOS) to an infant formula resulted in an increased number of bifidobacteria, and a reduced number of pathogens, as compared with infants receiving an unsupplemented formula. At a concentration of $0.8 \mathrm{~g}$ oligosaccharides $/ 100 \mathrm{ml}$ formula, the amount of bifidobacteria became similar to that typical of breast-fed infants.

TOS can also influence GI microbial composition. They can be utilised by bifidobacteria, lactobacilli, Bacteroides, streptococci and enterobacteria (Tanaka et al. 1983). A culture study by Smiricky-Tjardes et al. (2003) demonstrated the effect of dietary GOS on ileal and faecal bacterial communities in growing pigs. The authors found a significant increase in faecal bifidobacteria and lactobacilli for animals fed diets containing soya solubles and TOS.

Table 3 summarises some recent studies investigating the effects of different fermentable carbohydrates on the composition of the GI microbiota. Results are sometimes conflicting, such as for the use of GOS studied under in vitro and in vivo conditions. Tzortzis et al. (2004) showed that GOS increased bifidobacteria in canine faeces in vitro, while in vivo, there was no effect on faecal bifidobacteria in a human feeding trial (Satokari et al. 2001). Such differences may depend, to some extent, upon the methodology and host species being used. However, it is clear that truly fermentable carbohydrates, chosen as appropriately for the host environment, can have a beneficial effect upon the intestinal microbial community of the young animal. Konstantinov et al. (2003, 2004a,b) introduced pretested (in vitro) fermentable carbohydrates to newly weaned piglets' diets, which resulted in a greater diversity and more rapid stabilisation of the GI community. It has also been shown that the introduction of fermentable carbohydrates not only resulted in increased beneficial bacteria (bifidobacteria, lactobacilli), but also in decreases in potentially harmful bacteria, such as $C$. difficile (Hopkins \& Macfarlane, 2003). Similarly, Konstantinov et al. (2004a), again using pre-tested fermentable carbohydrates in weaning piglet diets, showed a stimulation of lactobacilli, and a concomitant suppression of Clostridium-like species. 


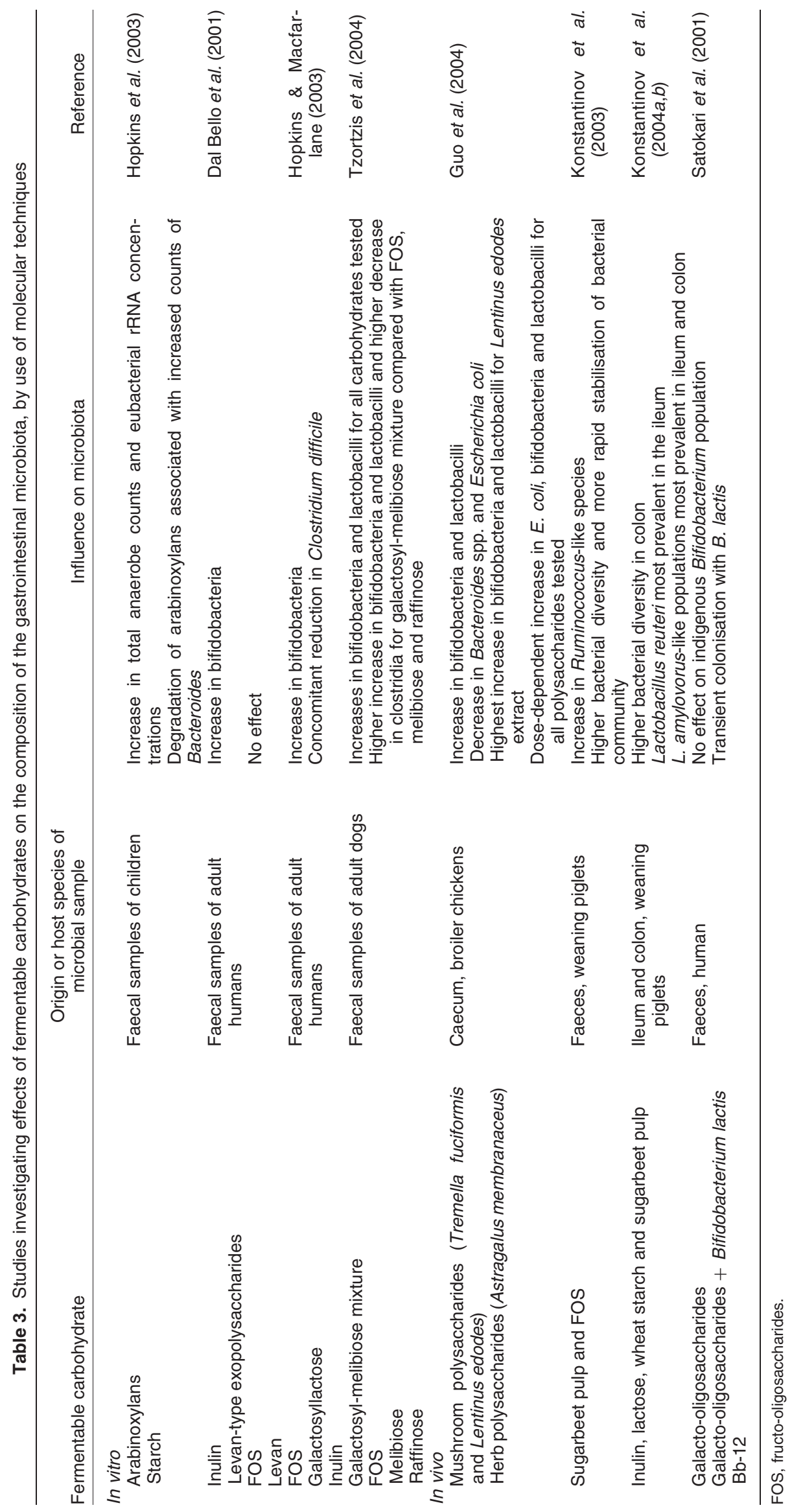




\section{Influence of fermentable carbohydrates on nitrogen metabolism in the intestine}

In the absence of sufficient energy as carbohydrate, some bacteria may use protein as a source of energy, resulting in the formation of potentially toxic substances such as $\mathrm{NH}_{3}$, amines and amides (Cummings \& Macfarlane, 1991; Macfarlane et al. 1992). However, if sufficient fermentable carbohydrate is available, bacteria may utilise $\mathrm{NH}_{3}$ as an $\mathrm{N}$ source for their own growth (Bryant \& Robinson, 1962). Accordingly, provision of fermentable carbohydrates can increase $\mathrm{NH}_{3}$ uptake by GI bacteria. $\mathrm{N}$ would then be excreted as microbial protein via the faeces instead of as urea in urine, saving energy to the host and reducing the $\mathrm{NH}_{3}$ burden to the environment (Mosenthin et al. 1992, 1994; Canh et al. 1998). For example, the addition of oligofructose to a rat diet $(7.5 \mathrm{~g}$ per $100 \mathrm{~g}$ diet $)$ reduced blood urea and urinary $\mathrm{N}$ by $20-30 \%$ (Younes et al. 1995). This phenomenon was also shown by Canh et al. (1997), who investigated the influence of dietary NSP (sugarbeet pulp) on $\mathrm{N}$ partitioning of urine and faeces of fattening pigs. They found that the pigs fed the sugarbeet pulp-based diet excreted 22-37\% less urea in urine than the pigs fed diets with a lower NSP content.

Van Nuenen et al. (2003) investigated the effect of inulin on the metabolic activity of the human colonic microbiota with or without the addition of $C$. difficile in vitro. The addition of inulin stimulated the total SCFA production, while suppressing formation of $\mathrm{NH}_{3}$ and branched-chain fatty acids. While the introduction of $C$. difficile stimulated the production of protein-fermentative metabolites such as $\mathrm{NH}_{3}$, branched-chain fatty acids and phenolic compounds (for example, indole), this was almost completely avoided by the addition of inulin. It appeared that inulin has the potential to shift the metabolic activity of the human colonic microbiota away from the production of toxic metabolites, both under normal conditions, and under conditions with a disturbed microbiota, i.e. in this case with a higher proportion of $C$. difficile.

\section{Conclusions}

Diet appears to be an important factor controlling the composition and metabolic activities of the GI microbiota of single-stomached animals and man. Insufficient work has been done to understand the effect of dietary fat on the single-stomached microbiota. However, any influence is most likely to be direct antimicrobial action, as has been shown for some MCFA and their derivatives, such as some milk lipids, or possibly through interaction with bile acid metabolism. It is generally assumed that fat in the gut of single-stomached species is completely absorbed before it can have any effect on colonic bacteria. This assumption would be invalid, however, for animals or human subjects with small-intestinal disturbances which are associated with poor digestion or fat absorption.

Fermentation of proteins is associated with the growth of potentially pathogenic bacteria and toxic metabolite production, while the fraction of non-digestible (but fermentable) carbohydrates seems to exert beneficial influences on the composition and activity of the GI microbiota. Such carbohydrates may enhance the healthpromoting properties of the GI microbiota, such as colonisation resistance against invading pathogens, or production of SCFA and reduction of detrimental substances. Particular focus has centred on the use of prebiotics which selectively stimulate beneficial GI bacteria such as lactobacilli or bifidobacteria. Fermentable carbohydrate supplementation seems to stimulate bacterial diversity in newly weaned piglets, which seems to be essential for rapid stabilisation of the microbial community (Konstantinov et al. 2003). Such a mechanism is of special importance for the young animal or infant, in times of rapid change or stress, such as the time of intestinal colonisation after birth or during weaning.

As can be seen from compositional differences in the GI microbiota between breast-fed and formula-fed infants, early diet has a major impact on microbial development. Specific components of maternal milk might support colonisation of the neonate animal or infant with a beneficial microbiota, partly by acting as growth promoters for beneficial bacteria, and partly by exerting antimicrobial activities against potential pathogens. For example, oligosaccharides present in human milk display homology to cell surface pathogen receptors and may therefore inhibit pathogen interactions with host mucosal tissues, so protecting from infection. Prebiotics incorporating such receptor oligosaccharide sequences would then act as 'decoy' molecules for potential pathogenic bacteria (Steer et al. 2000).

However, it is not only oligosaccharides which may stimulate beneficial microbiota. It seems that there are more fermentable carbohydrates with prebiotic properties. In terms of health, larger, more slowly fermentable polysaccharides might provide an advantage over the rapidly fermented oligosaccharides currently used as prebiotics, by providing a carbohydrate source for SCFA production and suppression of protein metabolism more distally in the colon. Indeed, there is increasing evidence to suggest that some NDO are completely fermented either by the terminal ileum (FOS) or within the proximal large intestine (TOS), and are therefore unavailable for bacteria in the distal colon (Houdijk, 1998). In vitro fermentation studies using faecal inocula have shown that arabinoxylan may be used by Bifidobacterium longum as a carbon source (Crittenden et al. 2002). Attention should be given, not only to manufactured prebiotics, but also to more 'natural prebiotics', i.e. specific feedstuffs containing fermentable carbohydrates that might enhance microbial activity in a positive way and therefore improve GI health. However, degradation of polysaccharides in the GIT is a process involving consortia of several bacterial species. This means that various factors have to be taken into account, such as substrate availability, nutrient competition, population dynamics and host factors. The possible immunostimulatory action of some polysaccharides (for example, $\beta$-glucans) might also be of interest, raising the possibility of an immune-system-related influence on intestinal microbiota, exerted by dietary components.

One should also consider that other bacterial species, apart from the 'classic' easily cultivated bacteria, such as lactobacilli and bifidobacteria, may exert beneficial 
influences and be stimulated by specific dietary components. However, the metabolic properties of these bacteria will have to be defined so as to determine their role in colonic metabolism and GI health.

Nutrition of livestock must always include economic considerations, so the potential of dietary modulation of the GI microbiota must be related to improvements in animal health, rather than any change in feed efficiency. Nevertheless, it is essential to understand the colonisation process and the interactions between the host diet and its microbiota. This may aid in predicting the effects of specific dietary components on the development of a beneficial microbiota, and the long-term effects on microbial composition, in order to improve host health, particularly in young animals at the time of weaning, or at other stressful moments in animals' lives. This will be of particular interest as the use of antibiotics as growth promoters is completely banned from animal feeds within the European Union.

\section{Acknowledgements}

The writing of the present review was supported by the Dutch Commodity Board for Animal Feedstuffs.

\section{References}

Adrian J (1976) Gums and hydrocolloids in nutrition. World Review of Nutrition and Dietetics 25, 189-216.

Amann RI, Ludwig W \& Schleifer KH (1995) Phylogenetic identification and in situ detection of individual microbial cells without cultivation. Microbiological Reviews 59, 143-169.

Balmer SE, Hanvey LS \& Wharton BA (1994) Diet and faecal flora in the newborn: nucleotides. Archives of Disease in Childhood, 70F, 137-140.

Balmer SE \& Wharton BA (1989) Diet and faecal flora in the newborn: breast milk and infant formula. Archives of Disease in Childhood 64, 1672-1677.

Barrow PA (1992) Probiotics for chicken. In Probiotics: The Scientific Approach, pp. 225-259 [R Fuller, editor]. London: Chapman and Hall.

Bauer E, Williams BA, Bosch MW, Voigt C, Mosenthin R \& Verstegen MWA (2004) Differences in microbial activity of digesta from three sections of the porcine large intestine according to in vitro fermentation of carbohydrate-rich substrates. Journal of the Science of Food and Agriculture 84, 2097-2104.

Bauer E, Williams BA, Voigt C, Mosenthin R \& Verstegen MWA (2001) Microbial activities of faeces from unweaned and adult pigs, in relation to selected fermentable carbohydrates. Animal Science 73, 313-322.

Beasley SS \& Saris PEJ (2004) Nisin-producing Lactococcus lactis strains isolated from human milk. Applied and Environmental Microbiology 70, 5051-5053.

Beerens H, Romond C \& Neut C (1980) Influence of breastfeeding on the bifid flora of the newborn intestine. American Journal of Clinical Nutrition 33, 2434-2439.

Bergsson G, Arnfinnsson J, Steingrimsson O \& Thormar H (2001) Killing of Gram-positive cocci by fatty acids and monoglycerides. APMIS: Acta Pathologica, Microbiologica, et Immunologica Scandinavica 109, 670-678.

Bezkorovainy A \& Topouzian N (1981) Bifidobacterium bifidus var. pennsylvanicus growth promoting activity of human milk casein and its derivatives. International Journal of Biochemistry 13, 585-590.
Boehm G, Jelinek J, Stahl B, Van Laere K, Knol J, Fanaro S, Moro G \& Vigi V (2004) Prebiotics in infant formulas. Journal of Clinical Gastroenterology 38, S76-S79.

Botham RL, Ryden P, Robertson JA \& Ring SG (1998) Structural features of polysaccharides and their influence on fermentation behaviour. In Functional Properties of Nondigestible Carbohydrates, pp. 46-49 [F Guillon, editor]. Nantes: INRA.

Brandtzaeg P (2003) Role of secretory antibodies in the defence against infections. International Journal of Medical Microbiology 293, 3-15.

Brock JH (1980) Lactoferrin in human milk: its role in iron absorption and protection against enteric infection in the newborn infant. Archives of Disease in Childhood 55, 417-421.

Brody EP (2000) Biological activities of bovine glycomacropeptide. British Journal of Nutrition 84, S39-S46.

Brown I, Warhurst M, Arcot J, Playne M, Illman RJ \& Topping DL (1997) Fecal numbers of bifidobacteria are higher in pigs fed Bifidobacterium longum with a high amylose cornstarch than with a low amylose cornstarch. Journal of Nutrition 127, $1822-1827$.

Bruininx EM, Binnendijk GP, Van der Peet-Schwering CM, Schrama JW, Den Hartog LA, Everts H \& Beynen AC (2002) Effect of creep feed consumption on individual feed intake characteristics and performance of group-housed weanling pigs. Journal of Animal Science 80, 1413-1418.

Bryant MP \& Robinson IM (1962) Some nutritional characteristics of predominant culturable ruminal bacteria. Journal of Bacteriology 84, 605-614.

Bullen CL, Tearle PV \& Willis AT (1976) Bifidobacteria in the intestinal tract of infants: an in-vivo study. Journal of Medical Microbiology 9, 325-333.

Bullen JJ (1975) Iron-binding proteins in milk and resistance to Escherichia coli infection in infants. Postgraduate Medical Journal 51, 67-70.

Butler JE (1998) Immunoglobulin diversity, B-cell and antibody repertoire development in large farm animals. Scientific and Technical Review 17, 43-70.

Canh TT, Sutton AL, Aarnink AJA, Verstegen MWA, Schrama JW \& Bakker GCM (1998) Dietary carbohydrates alter the fecal composition and $\mathrm{pH}$ and the ammonia emission from slurry of growing pigs. Journal of Animal Science 76, 1887-1895.

Canh TT, Verstegen MW, Aarnink AJ \& Schrama JW (1997) Influence of dietary factors on nitrogen partitioning and composition of urine and feces of fattening pigs. Journal of Animal Science 75, 700-706.

Carlson SE (1985) N-acetylneuraminic acid concentrations in human milk oligosaccharides and glycoproteins during lactation. American Journal of Clinical Nutrition 41, 720-726.

Carroll L, Osman M, Davies DP \& McNeish AS (1979) Bacteriological criteria for feeding raw breast-milk to babies on neonatal units. Lancet ii, 732-733.

Champ M, Langkilde A-M, Brouns F, Kettlitz B \& Le Bail-Collet Y (2003) Advances in dietary fibre characterisation. 2. Consumption, chemistry, physiology and measurement of resistant starch; implications for health and food labelling. Nutrition Research Reviews 16, 143-161.

Chipman DM \& Sharon N (1969) Mechanism of lysozyme action. Science 165, 454-465.

Choct M \& Annison G (1992) Anti-nutritive effect of wheat pentosans in broiler chickens: roles of viscosity and gut microflora. British Poultry Science 33, 821-834.

Christensen K \& Thorbek G (1987) Methane excretion in the growing pig. British Journal of Nutrition 57, 355-361.

Chung KT, Fulk GE \& Silverman SJ (1977) Dietary effects on the composition of fecal flora of rats. Applied and Environmental Microbiology 33, 654-659. 
Clark S, Brause B \& Holt P (1969) Lipolysis and absorption of fat in the rat stomach. Gastroenterology 56, 214-222.

Crittenden R, Karppinen S, Ojanen S, Tenkanen M, Fagerström R, Mättö J, Saarela M, Mattila-Sandholm T \& Poutanen K (2002) In vitro fermentation of cereal dietary fibre carbohydrates by probiotic and intestinal bacteria. Journal of the Science of Food and Agriculture 82, 781-789.

Cummings JH \& Englyst HN (1987) Fermentation in the human large intestine and the available substrates. American Journal of Clinical Nutrition 45, 1243-1255.

Cummings JH \& Macfarlane GT (1991) The control and consequences of bacterial fermentation in the human colon. Journal of Applied Bacteriology 70, 443-459.

Cummings JH, Wiggins HS, Jenkins DJ, Houston H, Jivraj T, Drasar BS \& Hill MJ (1978) Influence of diets high and low in animal fat on bowel habit, gastrointestinal transit time, fecal microflora, bile acid, and fat excretion. Journal of Clinical Investigation 61, 953-963.

Dal Bello F, Walter J, Hertel C \& Hammes WP (2001) In vitro study of prebiotic properties of levan-type exopolysaccharides from lactobacilli and non-digestible carbohydrates using denaturing gradient gel electrophoresis. Systematic and Applied Microbiology 24, 232-237.

Dänicke S, Simon O, Jeroch H \& Bedford M (1997) Interactions between dietary fat type and xylanase supplementation when rye-based diets are fed to broiler chickens. 1. Physico-chemical chyme features. British Poultry Science 38, 537-545.

Dänicke S, Vahjen W, Simon O \& Jeroch H (1999) Effects of dietary fat type and xylanase supplementation to rye-based broiler diets on selected bacterial groups adhering to the intestinal epithelium, on transit time of feed, and on nutrient digestibility. Poultry Science 78, 1292-1299.

Decuypere JA \& Dierick NA (2003) The combined use of triacylglycerols containing medium-chain fatty acids and exogenous lipolytic enzymes as an alternative to in-feed antibiotics in piglets: concept, possibilities and limitations. An overview. Nutrition Research Reviews 16, 193-209.

De Lange CFM (2000) Characterization of the non-starch polysaccharides. In Feed Evaluation - Principles and Practice, pp. 77-92 [PJ Moughan, MWA Verstegen and MI VisserReyneveld, editors]. Wageningen, The Netherlands: Wageningen Pers.

Dierick NA, Decuypere JA, Molly K, Van Beek E \& Vanderbeke E (2002a) The combined use of triacylglycerols containing medium-chain fatty acids (MCFAs) and exogenous lipolytic enzymes as an alternative for nutritional antibiotics in piglet nutrition: I. In vitro screening of the release of MCFAs from selected fat sources by selected exogenous lipolytic enzymes under simulated pig gastric conditions and their effects on the gut flora of piglets. Livestock Production Science 75, 129-142.

Dierick NA, Decuypere JA, Molly K, Van Beek E \& Vanderbeke E (2002b) The combined use of triacylglycerols (TAGs) containing medium chain fatty acids (MCFAs) and exogenous lipolytic enzymes as an alternative to nutritional antibiotics in piglet nutrition: II. In vivo release of MCFAs in gastric cannulated and slaughtered piglets by endogenous and exogenous lipases; effects on the luminal gut flora and growth performance. Livestock Production Science 76, 1-16.

Dongowski G, Huth M, Gebhardt E \& Flamme W (2002) Dietary fiber-rich barley products beneficially affect the intestinal tract of rats. Journal of Nutrition 132, 3704-3714.

Edde L, Hipolito RB, Hwang FF, Headon DR, Shalwitz RA \& Sherman MP (2001) Lactoferrin protects neonatal rats from gutrelated systemic infection. American Journal of Physiology, 281G, 1140-1150.
Edney MJ, Marchylo BA \& MacGregore AW (1991) Structure of total barley $\beta$-glucan. Journal of the Institute of Brewing 97, $39-44$.

Edwards CA \& Parrett AM (2002) Intestinal flora during the first months of life: new perspectives. British Journal of Nutrition 88, S11-S18.

Eidelman AI \& Szilagyi G (1979) Patterns of bacterial colonization of human milk. Obstetrics and Gynecology 53, 550-552.

Ekhart PF \& Timmermans E (1996) Techniques for the production of transgalactosylated oligosaccharides (TOS). Bulletin/International Dairy Federation 313, 59-64.

Elliot JI, Senft B, Erhardt G \& Fraser D (1984) Isolation of lactoferrin and its concentration in sows' colostrum and milk during a 21-day lactation. Journal of Animal Science 59, $1080-1084$.

Engfer MB, Stahl B, Finke B, Sawatzki G \& Daniel H (2000) Human milk oligosaccharides are resistant to enzymatic hydrolysis in the upper gastrointestinal tract. American Journal of Clinical Nutrition 71, 1589-1596.

Englyst HN, Bingham SA, Runswick SA, Collinson E \& Cummings JH (1989) Dietary fibre (non-starch-polysaccharides) in cereal products. Journal of Human Nutrition and Dietetics 2 , 253-271.

Englyst HN, Kingman SM \& Cummings JH (1992) Classification and measurement of nutritionally important starch fractions. European Journal of Clinical Nutrition 46, S33-S50.

Ewing WN \& Cole DJA (1994) The Living Gut. Dungannon, UK: Context Publications.

Favier C, Vaughan EE, De Vos WM \& Akkermans ADL (2002) Molecular monitoring of succession of bacterial communities in human neonates. Applied and Environmental Microbiology 68, 219-226.

Franklin MA, Mathew AG, Vickers JR \& Clift RA (2002) Characterization of microbial populations and volatile fatty acids concentrations in the jejunum, ileum, and cecum of pigs weaned at 17 vs 24 days of age. Journal of Animal Science 80, 2904-2910.

Fuller MF, Franklin MF, McWilliam R \& Pennie K (1995) The responses of growing pigs, of different sex and genotype, to dietary energy and protein. Animal Science 60, 291-298.

Gaskins HR (2001) Intestinal bacteria and their influence on swine growth. In Swine Nutrition, 2nd ed., pp. 585-608 [AJ Lewis and LL Southern, editors]. Boca Raton, FL: CRC Press LLC.

Gavin A \& Ostovar K (1977) Microbiological characterization of human milk. Journal of Food Protection 40, 614-616.

Gibson GR \& Roberfroid MB (1995) Dietary modulation of the human colonic microbiota: introducing the concept of prebiotics. Journal of Nutrition 125, 1401-1412.

Gil A, Corral E, Martínez-Valverde A \& Molina JA (1986) Effects of the addition of nucleotides to an adapted milk formula on the microbial pattern of faeces in at term newborn infants. Journal of Clinical Nutrition and Gastroenterology 1, 127-132.

Gnoth MJ, Kunz C, Kinne-Saffran E \& Rudloff S (2000) Human milk oligosaccharides are minimally digested in vitro. Journal of Nutrition 130, 3014-3020.

Griffiths EA, Duffy LC, Schanbacher FL, Dryja D, Leavens A, Neiswander RL, Qiao H, DiRienzo D \& Ogra P (2003) In vitro growth responses of bifidobacteria and enteropathogens to bovine and human lactoferrin. Digestive Diseases and Sciences 48, 1324-1332.

Grizard D \& Barthomeuf C (1999) Non-digestible oligosaccharides used as prebiotic agents: mode of production and beneficial effects on animal and human health. Reproduction Nutrition Development 39, 563-588.

Gunn JS (2000) Mechanisms of bacterial resistance and response to bile. Microbes and Infection 2, 907-913. 
Guo, FC (2003) Mushroom and herb polysaccharides as alternative for antimicrobial growth promoters in poultry. $\mathrm{PhD}$ Thesis, Wageningen University, The Netherlands.

Guo FC, Williams BA, Kwakkel RP, Li HS, Li XP, Luo JY, Li WK \& Verstegen MWA (2004) Effects of mushroom and herb polysaccharides, as alternatives for an antibiotic, on the cecal microbial ecosystem in broiler chickens. Poultry Science 83, $175-182$.

György P, Jeanloz RW, von Nicolai H \& Zilliken F (1974) Undialyzable growth factors for Lactobacillus bifidus var. pennsylvanicus. Protective effect of sialic acid bound to glycoproteins and oligosaccharides against bacterial degradation. European Journal of Biochemistry 43, 29-33.

György P, Kuhn R, Rose CS \& Zilliken F (1954) Bifidus factor. II. Its occurrence in milk from different species and in other natural products. Archives of Biochemistry and Biophysics 48, 202-208.

Hamosh M (1998) Protective function of proteins and lipids in human milk. Biology of the Neonate 74, 163-176.

Harmsen HJ, Wildeboer-Veloo AC, Raangs GC, Wagendorp AA, Klijn N, Bindels JG \& Welling GW (2000) Analysis of intestinal flora development in breast-fed and formula-fed infants by using molecular identification and detection methods. Journal of Pediatric Gastroenterology and Nutrition 30, 61-67.

Heikkilä MP \& Saris PE (2003) Inhibition of Staphylococcus aureus by the commensal bacteria of human milk. Journal of Applied Microbiology 95, 471-478.

Hentges DJ, Marsh WW, Petschow BW, Thal WR \& Carter MK (1992) Influence of infant diets on the ecology of the intestinal tract of human flora-associated mice. Journal of Pediatric Gastroenterology and Nutrition 14, 146-152.

Hidaka H, Eida T, Takizawa T, Tokunaga T \& Tashiro Y (1986) Effects of fructo-oligosaccharides on intestinal flora and human health. Bifidobacteria Microflora 5, 37-50.

Hill IR \& Porter P (1974) Studies of bactericidal activity to Escherichia coli of porcine serum and colostral immunoglobulins and the role of lysozyme with secretory IgA. Immunology 26, 1239-1250.

Hillman K (2001) Bacteriological aspects of the use of antibiotics and their alternatives in the feed of non-ruminant animals. In Recent Advances in Animal Nutrition, pp. 107-134 [PC Garnsworthy and J Wiseman, editors]. Nottingham: Nottingham University Press.

Hoey L, Rowland IR, Lloyd AS, Clarke DB \& Wiseman H (2004) Influence of soya-based infant formula consumption on isoflavone and gut microflora metabolite concentrations in urine and on faecal microflora composition and metabolic activity in infants and children. British Journal of Nutrition 91, 607-616.

Holt C \& Jenness R (1984) Interrelationships of constituents and partition of salts in milk samples from eight species. Comparative Biochemistry and Physiology 77A, 275-282.

Hopkins MJ, Englyst HN, Macfarlane S, Furrie E, Macfarlane GT \& McBain AJ (2003) Degradation of cross-linked and noncross-linked arabinoxylans by the intestinal microbiota in children. Applied and Environmental Microbiology 69, 6354-6360.

Hopkins MJ \& Macfarlane GT (2003) Nondigestible oligosaccharides enhance bacterial colonization resistance against Clostridium difficile in vitro. Applied and Environmental Microbiology 69, 1920-1927.

Houdijk J (1998) Effects of non-digestible oligosaccharides in young pig diets. PhD Thesis, Wageningen University, The Netherlands.

Isaacs CE (2001) The antimicrobial function of milk lipids. Advances in Nutritional Research 10, 271-285.
Isaacs CE, Litov RE \& Thormar H (1995) Antimicrobial activity of lipids added to human milk, infant formula, and bovine milk. Journal of Nutritional Biochemistry 6, 362-366.

Isaacs CE \& Thormar H (1991) The role of milk-derived antimicrobial lipids as antiviral and antibacterial agents. Advances in Experimental Medicine and Biology 310, 159-165.

Jonsson E \& Hemmingsson S (1991) Establishment in the piglet gut of lactobacilli capable of degrading mixed-linked betaglucans. Journal of Applied Bacteriology 70, 512-516.

Jouany JP (1994) Manipulation of microbial activity in the rumen. Archiv für Tierernährung 46, 133-153.

Kabara JJ, Swieczkowski DM, Conley AJ \& Truant JP (1972) Fatty acids and derivatives as antimicrobial agents. Antimicrobial Agents and Chemotherapy 2, 23-28.

Karlsson K-A, Ångström J, Bergström J \& Lanne B (1992) Microbial interaction with animal cell surface carbohydrates. APMIS: Acta Pathologica, Microbiologica, et Immunologica Scandinavica 100, Suppl. 27, 71-83.

Kauf AC \& Kensinger RS (2002) Purification of porcine betacasein, N-terminal sequence, quantification in mastitic milk. Journal of Animal Science 80, 1863-1870.

King RH \& Pluske JR (2003) Nutritional management of the pig in preparation for weaning. In Weaning the Pig, pp. 37-48 [JR Pluske, J Le Dividich and MWA Verstegen, editors]. Wageningen, The Netherlands: Wageningen Academic Publishers.

Kirjavainen PV, Apostolou E, Arvola T, Salminen SJ, Gibson GR \& Isolauri E (2001) Characterizing the composition of intestinal microflora as a prospective treatment target in infant allergic disease. FEMS Immunology and Medical Microbiology 32, 1-7.

Kleessen B, Bunke H, Tovar K, Noack J \& Sawatzki G (1995) Influence of two infant formulas and human milk on the development of the faecal flora in newborn infants. Acta Paediatrica 84, 1347-1356.

Kleessen B, Elsayed NA, Loehren U, Schroedl W \& Krueger M (2003) Jerusalem artichoke stimulate growth of broiler chickens and protect them against endotoxins and potential cecal pathogens. Journal of Food Protection 66, 2171-2175.

Kleessen B, Stoof G, Proll J, Schmiedl D, Noack J \& Blaut M (1997) Feeding resistant starch affects fecal and cecal microflora and short-chain fatty acids in rats. Journal of Animal Science 75, 2453-2462.

Konstantinov SR, Awati A, Smidt H, Williams BA, Akkermans ADL \& De Vos WM (2004a) Specific response of a novel and abundant Lactobacillus amylovorus-like phylotype to dietary prebiotics in the guts of weaning piglets. Applied and Environmental Microbiology 70, 3821-3830.

Konstantinov SR, Favier CF, Zhu WY, Williams BA, Klüss J, Souffrant WB, De Vos WM, Akkermans ADL \& Smidt H (2004b) Microbial diversity studies of the porcine gastrointestinal ecosystem during weaning transition. Animal Research 53, 317-324.

Konstantinov SR, Zhu WY, Williams BA, Tamminga S, De Vos WM \& Akkermans ADL (2003) Effect of fermentable carbohydrates on piglet faecal bacterial communities as revealed by denaturing gradient gel electrophoresis analysis of $16 \mathrm{~S}$ ribosomal DNA. FEMS Microbiology Ecology 43, 225-235.

Kuda T, Enomoto T, Yano T \& Fujii T (2000) Cecal environment and TBARS level in mice fed corn oil, beef tallow and menhaden fish oil. Journal of Nutritional Science and Vitaminology 46, $65-70$.

Kunz C (1998) Complex oligosaccharides in infant nutrition. Monatsschrift Kinderheilkunde 146, S49-S56.

Kunz C \& Rudloff S (1993) Biological functions of oligosaccharides in human milk. Acta Paediatrica 82, 903-912.

Kunz C, Rudloff S, Baier W, Klein N \& Strobel S (2000) Oligosaccharides in human milk: structural, functional, and metabolic aspects. Annual Review of Nutrition 20, 699-722. 
Labbok MH, Clark D \& Goldman AS (2004) Breastfeeding: maintaining an irreplaceable immunological resource. Nature Reviews Immunology 4, 565-572.

Leser TD, Amenuvor JZ, Jense TK, Lindecrona RH, Boye M \& Møller K (2002) Culture-independent analysis of gut bacteria: the pig gastrointestinal tract microbiota revisited. Applied and Environmental Microbiology 68, 673-690.

Liepke C, Adermann K, Raida M, Magert HJ, Forssmann WG \& Zucht HD (2002) Human milk provides peptides highly stimulating the growth of bifidobacteria. European Journal of Biochemistry 269, 712-718.

Lönnerdal B \& Iyer S (1995) Lactoferrin: molecular structure and biological function. Annual Review of Nutrition 15, 93-110.

Lundequist B, Nord CE \& Winberg J (1985) The composition of the faecal microflora in breastfed and bottle fed infants from birth to eight weeks. Acta Paediatrica Scandinavica 74, 45-51.

McBurney MI, Thompson LU, Cuff DJ \& Jenkins DJA (1988) Comparison of ileal effluents, dietary fibres, and whole foods in predicting the physiological importance of colonic fermentation. American Journal of Gastroenterology 83, 536-540.

McDonald, DE (2001) Dietary fibre for the newly weaned pig: influences on pig performance, intestinal development and expression of experimental postweaning colibacillosis and intestinal spirochaetosis. $\mathrm{PhD}$ Thesis, Murdoch University, Perth

Macfarlane GT, Cummings JH \& Allison C (1986) Protein degradation by human intestinal bacteria. Journal of General Microbiology 132, 1647-1656.

Macfarlane GT, Gibson GR \& Cummings JH (1992) Comparison of fermentation reactions in different regions of the human colon. Journal of Applied Bacteriology 72, 57-64.

Macfarlane S \& Macfarlane GT (1995) Proteolysis and amino acid fermentation. In Human Colonic Bacteria: Role in Nutrition, Physiology and Pathology, pp. 75-100 [GR Gibson and GT Macfarlane, editors]. Boca Raton, FL: CRC Press.

Mackie RI \& White BA (1997) Gastrointestinal Microbiology. New York: Chapman and Hall.

Mackie RI, Sghir A \& Gaskins HR (1999) Developmental microbial ecology of the neonatal gastrointestinal tract. American Journal of Clinical Nutrition 69, 1035-1045.

McVeagh P \& Miller JB (1997) Human milk oligosaccharides: only the breast. Journal of Paediatrics and Child Health 33, 281-286.

Marteau P, Pochart P, Doré J, Béra-Maillet C, Bernallier A \& Corthier G (2001) Comparative study of bacterial groups within the human cecal and fecal microbiota. Applied and Environmental Microbiology 67, 4939-4942.

Martín R, Langa S, Reviriego C, Jiminez E, Marin ML, Olivares M, Boza J, Jiminez J, Fernandez L, Xaus J \& Rodriguez JM (2004) The commensal microflora of human milk: new perspectives for food bacteriotherapy and probiotics. Trends in Food Science and Technology 15, 121-127.

Martín R, Langa S, Reviriego C, Jiminez E, Marin ML, Xaus J, Fernandez L \& Rodriguez JM (2003) Human milk is a source of lactic acid bacteria for the infant gut. Journal of Pediatrics 143, $754-758$.

Masson PL \& Heremans JF (1971) Lactoferrin in milk from different species. Comparative Biochemistry and Physiology 39B, 119-129.

Meisel H (1986) Chemical characterization and opioid activity of an exorphin isolated from in vivo digests of casein. FEBS Letters 196, 223-227.

Meisel H \& Frister H (1989) Chemical characterization of bioactive peptides from in vivo digests of casein. Journal of Dairy Research 56, 343-349.
Mikkelsen LL, Bendixen C, Jacobsen M \& Jensen BB (2003) Enumeration of bifidobacteria in gastrointestinal samples from piglets. Applied and Environmental Microbiology 69, 654-658.

Moro G, Minoli I, Mosca M, Fanaro S, Jelinek J, Stahl B \& Boehm G (2002) Dosage-related bifidogenic effects of galacto- and fructooligosaccharides in formula-fed term infants. Journal of Pediatric Gastroenterology and Nutrition 34, 291-295.

Mosenthin R, Sauer WC \& Ahrens F (1994) Dietary pectin's effect on ileal and fecal amino acid digestibility and exocrine pancreatic secretions in growing pigs. Journal of Nutrition 124, 1222-1229.

Mosenthin R, Sauer WC, Henkel H, Ahrens F \& De Lange CFM (1992) Tracer studies of urea kinetics in growing pigs: II. The effect of starch infusion at the distal ileum on urea recycling and bacterial nitrogen excretion. Journal of Animal Science 70, 3467-3472.

Moughan PJ, Birtles MJ, Cranwell PJ, Smith WC \& Pedraza M (1992) The piglet as a model animal for studying aspects of digestion and absorption in milk-fed human infants. In Nutritional Triggers for Health and in Disease, pp. 40-113 [AP Simopoulos, editor]. Basel: Karger.

Nagy LK, Mackenzie T \& Bharucha Z (1976) In vitro studies on the antimicrobial effects of colostrum and milk from vaccinated and unvaccinated pigs on Escherichia coli. Research in Veterinary Science 21, 132-140.

Naito S, Hayashidani H, Kaneko K, Ogawa M \& Benno Y (1995) Development of intestinal lactobacilli in normal piglets. Journal of Applied Bacteriology 79, 230-236.

Netherwood T, Gilbert HJ, Parker DS \& O’Donnell AG (1999) Probiotics shown to change bacterial community structure in the avian gastrointestinal tract. Applied and Environmental Microbiology 65, 5134-5138.

Newburg DS (1999) Human milk glycoconjugates that inhibit pathogens. Current Medicinal Chemistry 6, 117-127.

Nuijens JH, Van Berkel PH \& Schanbacher FL (1996) Structure and biological actions of lactoferrin. Journal of Mammary Gland Biology and Neoplasia 1, 285-295.

Okubo T, Ishihara N, Takahash H, Fujisawa T, Kim M, Yamamoto T \& Misuoka T (1994) Effects of partially hydrolysed guar gum intake in human intestinal microflora and its metabolism. Bioscience, Biotechnology, and Biochemistry 58, 1364-1369.

O'Sullivan D (1999) Methods for analysis of the intestinal microflora. In Probiotics: a Critical Review, pp. 23-44 [GW Tannock, editor]. Wymondham, UK: Horizon Scientific Press.

Ouwehand AC, Salminen SJ, Skurnik M \& Conway P (1997) Inhibition of pathogen adhesion by $\beta$-lactoglobulin. International Dairy Journal 7, 685-692.

Parrett AM \& Edwards CA (1997) In vitro fermentation of carbohydrate by breast fed and formula fed infants. Archives of Disease in Childhood 76, 249-253.

Parrett AM, Edwards CA \& Lokerse E (1997) Colonic fermentation capacity in vitro: development during weaning in breast-fed infants is slower for complex carbohydrates than for sugars. American Journal of Clinical Nutrition 65, 927-933.

Pellegrini A, Thomas U, Bramaz N, Hunziker P \& von Fellenberg R (1999) Isolation and identification of three bactericidal domains in the bovine alpha-lactalbumin molecule. Biochimica et Biophysica Acta 1426, 439-448.

Peterson JA, Patton S \& Hamosh M (1998) Glycoproteins of the human milk fat globule in the protection of the breast-fed infant against infections. Biology of the Neonate 74, 143-162.

Petschow BW, Batema RP, Talbott RD \& Ford LL (1998) Impact of medium-chain monoglycerides on intestinal colonisation by Vibrio cholerae or enterotoxigenic Escherichia coli. Journal of Medical Microbiology 47, 383-389.

Petschow BW \& Talbott RD (1990) Growth promotion of Bifidobacterium species by whey and casein fractions from 
human and bovine milk. Journal of Clinical Microbiology 28, 287-292.

Petschow BW \& Talbott RD (1991) Response of bifidobacterium species to growth promoters in human and cow milk. Pediatric Research 29, 208-213.

Pittard WB III, Geddes KM, Brown S, Mintz S \& Hulsey TC (1991) Bacterial contamination of human milk: container type and method of expression. American Journal of Perinatology $\mathbf{8}$, 25-27.

Poch M \& Bezkorovainy A (1991) Bovine milk к-casein trypsin digest is a growth enhancer for the genus Bifidobacterium. Journal of Agricultural and Food Chemistry 39, 73-77.

Rathbone EB (1980) Raffinose and melezitose. In Developments in Food Carbohydrate, pp. 146-149 [CK Lee, editor]. London: Applied Science Publisher Ltd.

Ross AH, Eastwood MA, Brydon WG, Anderson JR \& Anderson DM (1983) A study of the effects of dietary gum arabic in humans. American Journal of Clinical Nutrition 37, 368-375.

Rudloff S \& Kunz C (1997) Protein and nonprotein nitrogen components in human milk, bovine milk, and infant formula: quantitative and qualitative aspects in infant nutrition. Journal of Pediatric Gastroenterology and Nutrition 24, 328-344.

Rueda R, Sabatel JL, Maldonado J, Molina-Font JA \& Gil A (1998) Addition of gangliosides to an adapted milk formula modifies levels of fecal Escherichia coli in preterm newborn infants. Journal of Pediatrics 133, 90-94.

Salmon H (1999) The mammary gland and neonate mucosal immunity. Veterinary Immunology and Immunopathology 72, $143-155$.

Salyers AA, West SEH, Vercelotti JR \& Wilkins TD (1977) Fermentation of mucins and plant polysaccharides by anaerobic bacteria from the human colon. Applied and Environmental Microbiology 34, 529-533.

Sanchez L, Calvo M \& Brock JH (1992) Biological role of lactoferrin. Archives of Disease in Childhood 67, 657-661.

Satokari RM, Vaughan EE, Akkermans ADL, Saarela M \& De Vos WM (2001) Polymerase chain reaction and denaturing gradient gel electrophoresis monitoring of fecal Bifidobacterium populations in a prebiotic and probiotic feeding trial. Systematic and Applied Microbiology 24, 227-231.

Savage DC (1977) Microbial ecology of the gastrointestinal tract. Annual Review of Microbiology 31, 107-133.

Schmelz EM, Crall KJ, Larocque R, Dillehay DL \& Merrill AH Jr (1994) Uptake and metabolism of sphingolipids in isolated intestinal loops of mice. Journal of Nutrition 124, 702-712.

Schroten H (2001) Chemistry of milk mucins and their antimicrobial action. In Advances in Nutritional Research, vol. 10, pp. 231-245 [B Woodward and HH Draper, editors]. New York: Plenum.

Schulze F \& Muller G (1980) Lysozyme in sow's milk and its importance to bacterial population of the gastrointestinal tract in suckling piglets. Archiv für Experimentelle Veterinärmedizin 34, 317-324.

Silvi S, Rumney CJ, Cresci A \& Rowland IR (1999) Resistant starch modifies gut microflora and microbial metabolism in human flora-associated rats inoculated with faeces from Italian and UK donors. Journal of Applied Microbiology 86, 521-530.

Simpson JM, McCracken VJ, Gaskins HR \& Mackie RI (2000) Denaturing gradient gel electrophoresis analysis of $16 \mathrm{~S}$ ribosomal DNA amplicons to monitor changes in fecal bacterial populations of weaning pigs after introduction of Lactobacillus reuteri strain MM53. Applied and Environmental Microbiology 66, $4705-4714$.

Smiricky-Tjardes MR, Grieshop CM, Flickinger EA, Bauer LL \& Fahey GC Jr (2003) Dietary galactooligosaccharides affect ileal and total-tract nutrient digestibility, ileal and fecal bacterial concentrations, and ileal fermentative characteristics of growing pigs. Journal of Animal Science 81, 2535-2545.

Smith HW (1965) Development of the flora of the alimentary tract in young animals. Journal of Pathology and Bacteriology $\mathbf{9 0}$, 495-513.

Sprong RC, Hulstein MF \& Van der Meer R (2001) Bactericidal activities of milk lipids. Antimicrobial Agents and Chemotherapy 45, 1298-1301.

Staples A, Wang B \& Brand-Miller J (2002) Comparison of sialic acid content in sow's milk and pig milk replacers. Proceedings of the Nutrition Society of Australia 62, S237 Abstr.

Stark PL \& Lee A (1982) The microbial ecology of the large bowel of breast-fed and formula-fed infants during the first year of life. Journal of Medical Microbiology 15, 189-203.

Steer T, Carpenter H, Tuohy K \& Gibson GR (2000) Perspectives on the role of the human gut microbiota and its modulation by pro- and prebiotics. Nutrition Research Reviews 13, 229-254.

Stephen AM \& Cummings JH (1979) Water holding by dietary fibre in vitro and its relationship to faecal output in man. Gut $\mathbf{2 0}$, $722-729$.

Stewart CS (1997) Microorganisms in hindgut fermentors. In Gastrointestinal microbiology, pp. 142-186 [RI Mackie, BA White and RE Isaacson, editors]. New York: Chapman and Hall.

Strompfová V, Lauková A \& Ouwehand AC (2004) Selection of enterococci for potential canine probiotic additives. Veterinary Microbiology 100, 107-114.

Sutton AL \& Patterson JA (1996) Effects of dietary carbohydrates and organic acid additions on pathogenic E. coli and other microorganisms in the weanling pig. In Proceedings of the 5th International Symposium on Animal Nutrition, pp.31-61 [L Babinszky, editor]. Kapsovár, Hungary: PANNON Agricultural University, Faculty of Animal Science.

Tanaka R, Takayama H, Morotomi M, Kuroshima T, Ueyama S \& Matsumoto K (1983) Effects of administration of TOS and Bifidobacterium breve 4006 on the human fecal flora. Bifidobacteria Microflora 2, 17-24.

Tannock GW (2001) Molecular assessment of intestinal microflora. American Journal of Clinical Nutrition 73, 410S-414S.

Tannock GW, Fuller R \& Pedersen K (1990) Lactobacillus succession in the piglet digestive tract demonstrated by plasmid profiling. Applied and Environmental Microbiology 56, 1310-1316.

Tannock GW, Munro K, Harmsen HJ, Welling GW, Smart J \& Gopal PK (2000) Analysis of the fecal microflora of human subjects consuming a probiotic product containing Lactobacillus rhamnosus DR20. Applied and Environmental Microbiology 66, 2578-2588.

Tannock GW, Tangerman A, Van Schaik A \& McConnell MA (1994) Deconjugation of bile acids by lactobacilli in the mouse small bowel. Applied and Environmental Microbiology 60, 3419-3420.

Teitelbaum JE \& Walker WA (2002) Nutritional impact of pre- and probiotics as protective gastrointestinal organisms. Annual Review of Nutrition 22, 107-138.

Thoren-Tolling K \& Martinsson K (1974) On the transferrin concentration in serum of sows and growing pigs and in sow colostrum. Acta Veterinaria Scandinavica 15, 120-134.

Thormar H, Isaacs CE, Brown HR, Barshatzky MR \& Pessolano T (1987) Inactivation of enveloped viruses and killing of cells by fatty acids and monoglycerides. Antimicrobial Agents and Chemotherapy 31, 27-31.

Tomita M, Bellamy W, Takase M, Yamauchi K, Wakabayashi H \& Kawase K (1991) Potent antibacterial peptides generated by pepsin digestion of bovine lactoferrin. Journal of Dairy Science 74, 4137-4142.

Tsuchido T, Hiraoka T, Takano M \& Shibasaki I (1985) Involvement of autolysin in cellular lysis of Bacillus subtilis 
induced by short- and medium-chain fatty acids. Journal of Bacteriology 162, 42-46.

Tzortzis G, Goulas AK, Baillon M-LA, Gibson GR \& Rastall RA (2004) In vitro evaluation of the fermentation properties of galactooligosaccharides synthesised by $\alpha$-galactosidase from Lactobacillus reuteri. Applied Microbiology and Biotechnology 64, 106-111.

Van der Steen I, Rohde J, Zentek J \& Amtsberg G (1997) Fütterungseinflüsse auf das Vorkommen und die Enterotoxinbildung von Clostridium perfringens im Darmkanal des Hundes (Dietary effects on the occurrence of Clostridium perfringers and its enterotoxin in the intestine of dogs). Kleintierpraxis 42, 871-886.

Van der Waaij D, Berghuis De Vries JM \& Lekkerkerk Van der Wees JEC (1971) Colonization resistance of the digestive tract in conventional and antibiotic-treated mice. Journal of Hygiene $\mathbf{6 9}$, 405-411.

Van Loo J, Coussement P, De Leenherr L, Hoebregs H \& Smits G (1995) On the presence of inulin and oligofructose as natural ingredients in the western diet. Critical Reviews in Food Science and Nutrition 35, 525-552.

Van Nuenen MHMC, Meyer PD \& Venema K (2003) The effect of various inulins and Clostridium difficile on the metabolic activity of the human colonic microbiota in vitro. Microbial Ecology in Health and Disease 15, 137-144.

Varel VH, Pond WG \& Yen JT (1984) Influence of dietary fiber on the performance and cellulase activity of growing-finishing swine. Journal of Animal Science 59, 388-393.

Varel VH \& Yen JT (1997) Microbial perspective on fiber utilization by swine. Journal of Animal Science 75, 2715-2722.

Vaughan EE, Schut F, Heilig HG, Zoetendal EG, De Vos WM \& Akkermans AD (2000) A molecular view of the intestinal ecosystem. Current Issues in Intestinal Microbiology 1, 1-12.

Wagstrom EA, Yoon KJ \& Zimmerman JJ (2000) Immune components in porcine mammary secretions. Viral Immunology 13, 383-397.

Walker RI \& Owen RL (1990) Intestinal barriers to bacteria and their toxins. Annual Review of Medicine 41, 393-400.

Walter J, Tannock GW, Tilsala-Timisjarvi A, Rodtong S, Loach DM, Munro K \& Alatossava T (2000) Detection and identification of gastrointestinal Lactobacillus species by using denaturing gradient gel electrophoresis and species-specific PCR primers. Applied and Environmental Microbiology 66, 297-303.

Wang JF, Zhu YH, Li DF, Wang Z \& Jensen BB (2004) In vitro fermentation of various fiber and starch sources by pig fecal inocula. Journal of Animal Science 82, 2615-2622.

Wang LL \& Johnson EA (1992) Inhibition of Listeria monocytogenes by fatty acids and monoglycerides. Applied and Environmental Microbiology 58, 624-629.

Wang X, Brown IL, Khaled D, Mahoney MC, Evans AJ \& Conway PL (2002) Manipulation of colonic bacteria and volatile fatty acid production by dietary high amylose maize (amylomaize) starch granules. Journal of Applied Microbiology 93, 390-397.

Wang X \& Gibson GR (1993) Effects of the in vitro fermentation of oligofructose and inulin by bacteria growing in the human large intestine. Journal of Applied Bacteriology 75, 373-380.

West PA, Hewitt JH \& Murphy OM (1979) Influence of methods of collection and storage on the bacteriology of human milk. Journal of Applied Bacteriology 46, 269-277.

Williams BA, Bosch MW, Boer H, Verstegen MWA \& Tamminga S (2005) An in vitro batch culture method to assess potential fermentability of ingredients for monogastric diets. Animal Feed Science and Technology 123-124, 445-462.

Williams BA, Verstegen MWA \& Tamminga S (2001) Fermentation in the monogastric large intestine: its relation to animal health. Nutrition Research Reviews 14, 207-227.

Xu ZR, Zou XT, Hu CH, Xia MS, Zhan XA \& Wang MQ (2002) Effects of dietary fructooligosaccharides on digestive enzyme activities, intestinal microflora and morphology of growing pigs. Asian-Australasian Journal of Animal Sciences 15, 1784-1789.

Yamauchi K, Tomita M, Giehl TJ \& Ellison RT III (1993) Antibacterial activity of lactoferrin and a pepsin-derived lactoferrin peptide fragment. Infection and Immunity 61, 719-728.

Younes H, Garleb K, Behr S, Rémésy C \& Demigné C (1995) Fermentable fibres or oligosaccharides reduce urinary nitrogen excretion by increasing urea disposal in the rat cecum. Journal of Nutrition 125, 1010-1016.

Zentek J (1995a) Influence of diet composition on the microbial activity in the gastro-intestinal tract of dogs. I. Effects of varying protein intake on the composition of the ileum chyme and the faeces. Journal of Animal Physiology and Animal Nutrition 74, $43-52$.

Zentek J (1995b) Influence of diet composition on the microbial activity in the gastro-intestinal tract of dogs. II. Effects on the microflora in the ileum chyme. Journal of Animal Physiology and Animal Nutrition 74, 53-61.

Zhou J (2003) Microarrays for bacterial detection and microbial community analysis. Current Opinion in Microbiology 6, $288-294$.

Zoetendal EG, Collier CT, Koike S, Mackie RI \& Gaskins HR (2004) Molecular ecological analysis of the gastrointestinal microbiota: a review. Journal of Nutrition 134, 465-472.

Zoetendal EG, Von Wright A, Vilpponen-Salmela T, Ben-Amor K, Akkermans ADL \& De Vos WM (2002) Mucosa-associated bacteria in the human gastrointestinal tract are uniformly distributed along the colon and differ from the community recovered from feces. Applied and Environmental Microbiology 68, 3401-3407.

Zucht HD, Raida M, Adermann K, Magert HJ \& Forssmann WG (1995) Casocidin-I: a casein-alpha s2 derived peptide exhibits antibacterial activity. FEBS Letters 372, 185-188. 